\title{
Alpinia: the gold mine of future therapeutics
}

\author{
S. Ghosh · L. Rangan
}

Received: 4 May 2012/Accepted: 29 August 2012/Published online: 18 September 2012

(C) The Author(s) 2012. This article is published with open access at Springerlink.com

\begin{abstract}
Since prehistoric era, plant-derived drugs were much preferred due to their less side effects than drugs of synthetic origin. Bioassay-guided selection of active fraction of a plant extract and further isolation and characterization of the pure bioactive compounds are in practice in both academic and industrial research. Zingiberaceae, a medicinally important, ornamental, monocotyledonous family has potential members in the tribe Alpinieae, among which the genus Alpinia is studied under this current review due to its wide range of biomedical applications. The members in the genus possess many bioactive compounds against harmful microbes to deadly diseases like cancer by regulating the different signalling pathway systems. Several compounds have been discovered and found to deliver diversified biological efficacy either in vitro or in vivo against a range of diseases. The chemical profiling of the genus and investigation of crude essential oils and individual bioactive compounds towards the therapeutic importance in various disciplines have been documented in the current review.
\end{abstract}

Keywords Alpinia - Anticancer - Antioxidant . Bioactive compounds · Essential oil · Pharmacological

\section{Introduction}

Plant-derived drug research has become more promising in recent years and also a better alternative for synthetic medicine and therapeutics in spite of many challenges

S. Ghosh · L. Rangan ( $)$

Department of Biotechnology, Indian Institute of Technology

Guwahati, Guwahati 781039, Assam, India

e-mail: latha_rangan@yahoo.com; lrangan@iitg.ernet.in
(Vanwyk and Wink 2009). The bioactive natural compounds isolated from various parts of a plant are the key research thrust for a chemist, biologist, pharmacist, and medical professionals to tease and tap the potential of the so-called the 'wonder' molecules. In spite of great technological advancement in the field of applied science, medical treatments are still in its infancy when the treatment against the deadly diseases like cancer is considered. In many cases, it has been found that treatment of such diseases with the chemosynthetic drugs shows frequent side effects, toxicity, severe mental and physical abnormalities, not acceptable to the patient and to their families. Hence, the conservative mode of medical treatments and synthetic drugs available 'off the shelf' appears to be a serious concern.

Nearly, 21,000 plants have been listed by the World Health Organization (WHO), which are in use for diverse medicinal purposes around the world. Being the largest producer of medicinal herbs, India is known as the botanical garden of the world catering to the needs for herbal medicines (Seth and Sharma 2004). The WHO report revealed that around $80 \%$ of world population depends on the traditional medicines, largely on plant-derived drugs towards their healthcare, among which $30 \%$ of currently used therapeutics are from natural resources alone. Owing to the increasing cultural acceptability and significantly lower side effects, nearly $75-80 \%$ of the whole population in the developing countries mostly prefers the herbal treatment for primary health care (Ghasi et al. 2000).

Ethnopharmacogological knowledge towards the scientific investigation of medicinally important plants augments the prospects of alternative medicine and therapeutic values. The ethnomedical practices of the tribal communities of North East India were critically studied and documented for the Zingiberaceae family towards their future 
pharmacological diagnostics (Tushar et al. 2010). This important family is distributed worldwide with about 50 genera and 1,300 diverse species mainly concentrating in South and Southeast Asia (Wu and Larson 2000). In India, about 22 genera and 178 species have been reported from North Eastern and peninsular region (Jain and Prakash 1995), whereas North East region alone harbours 19 genera and close to about 88 diverse species (Prakash and Mehrotra 1995). Latin and species description in many cases are in doubtful identity.

The largest genus of the family Zingiberaceae, Alpinia, was classified by Charles Plumier, the famous French botanist and named after Prospero Alpino, the well-known Italian botanist of sixteenth century. The genus, Alpinia belongs to the flowering plants group (angiosperms); as per the Angiosperm Phylogeny Group II (APG II) system, it comes under the umbrella of monocotyledonous plants (Angiosperm Phylogeny Group 2003), belonging to the order Zingiberales, subfamily Alpinioideae and tribe Alpinieae. The genus includes 230-250 species distributed throughout tropical and subtropical climates of Asia and the Pacific. DNA-based studies showed the genus as polyphyletic represented by six clades scattered across the tribe Alpinieae (Kress et al. 2005).

Majority of the members of the genus produces attractive inflorescence, possesses aromatic aerial and underground parts generally subjected to different fractionation process for the extraction of essential oils, aqueous extract and bioactive components. Various parts of this plant have significant potential to yield bioactive components towards the development of future therapeutics (Fig. 1). The essential oil extracted from different parts of the plant contains diverse natural compounds having multiple medicinal properties. Because of its multipurpose utility, the genus Alpinia demands much attention from the researchers towards the development of potential therapeutics against various diseases like cancer, diabetes, ulcer and many neural disorders. Several research and reviews shows the importance and medical application of potential bioactive compounds isolated from different species of the genus and further research is continuing to unveil the mechanism of action of the natural bioactive compounds in regulating the disease progression and cure. The current aim of this study is to highlight the exhaustive pharmacological information and promising therapeutic uses of the genus Alpinia.

\section{Isolation and characterization of natural bioactive compound (phyotochemistry)}

The members of the genus Alpinia have complex chemical profiles and possess diverse flavonoids and are being considered as chemosystematic markers for the key identification and order classification (Pugialli et al. 1993). The flavonoids, in general, are known to be responsible for yellow pigmentation in plant tissues, and are potential source of antioxidants, many of which have anticancerous activities due to the presence of functional keto $(\mathrm{C}=\mathrm{O})$ or aldehyde (-CHO) groups (Williams et al. 2004). The aqueous and organic solvent extract harbours many bioactive compounds and their natural derivatives which differ from species to species and also plant parts used (rhizomes, stems, leaves, flowers, seeds and fruits) for isolation (Table 1).

Therefore, before exploitation of these natural compounds for diverse biological activities, isolation and characterization for each of them need to be done primarily by different spectral and analytical techniques. The isolation, chemical and molecular characterization of natural compounds has been done by standard bioanalytical techniques like preparative thin layer chromatography (pTLC), column chromatography (CC), high performance liquid chromatography (HPLC), ultraviolet (UV) spectral analysis, fourier transform infrared spectroscopy (FTIR), ${ }^{13} \mathrm{C}$ and ${ }^{1} \mathrm{H}$ nuclear magnetic resonance (NMR) and mass spectroscopy (MS). Till date, several bioactive compounds have been isolated and characterized from different species of the genus Alpinia. Some notable are enlisted in Table 1.

\section{Bio-pharmaceutical potential}

Reviewing of the genus Alpinia showed its incredible biopharmaceutical potentials as evident from earlier published reports and is gaining the attention of researchers from different disciplines. The presence of the bioactive substances such as flavonoids, tannins and terpenes is the key for its therapeutic efficiency. The potential biomedical applications of diverse species of Alpinia are depicted in Fig. 2. Brief accounts of its biological efficacy towards the therapeutic uses are described below.

\section{Antimicrobial activity}

A great depth of antimicrobial activities has been reported from Alpinia species having diverse chemical profile. Till date most of the work has been concentrated in A. galanga which contain more bioactive compounds compared to other species in the genera (Janssen and Scheffer 1985; Oonmetta-aree et al. 2006; Khattak et al. 2005; Weerakkody et al. 2011; Rao et al. 2010; Niyomkam et al. 2010). Essential oil extracted from fresh and dried rhizomes of A. galanga have potential antimicrobial activities against a range of bacteria, fungi, yeast and parasite. Ethanol extract from rhizome showed cytological modification to Staphyllococcus aureus cells by altering 

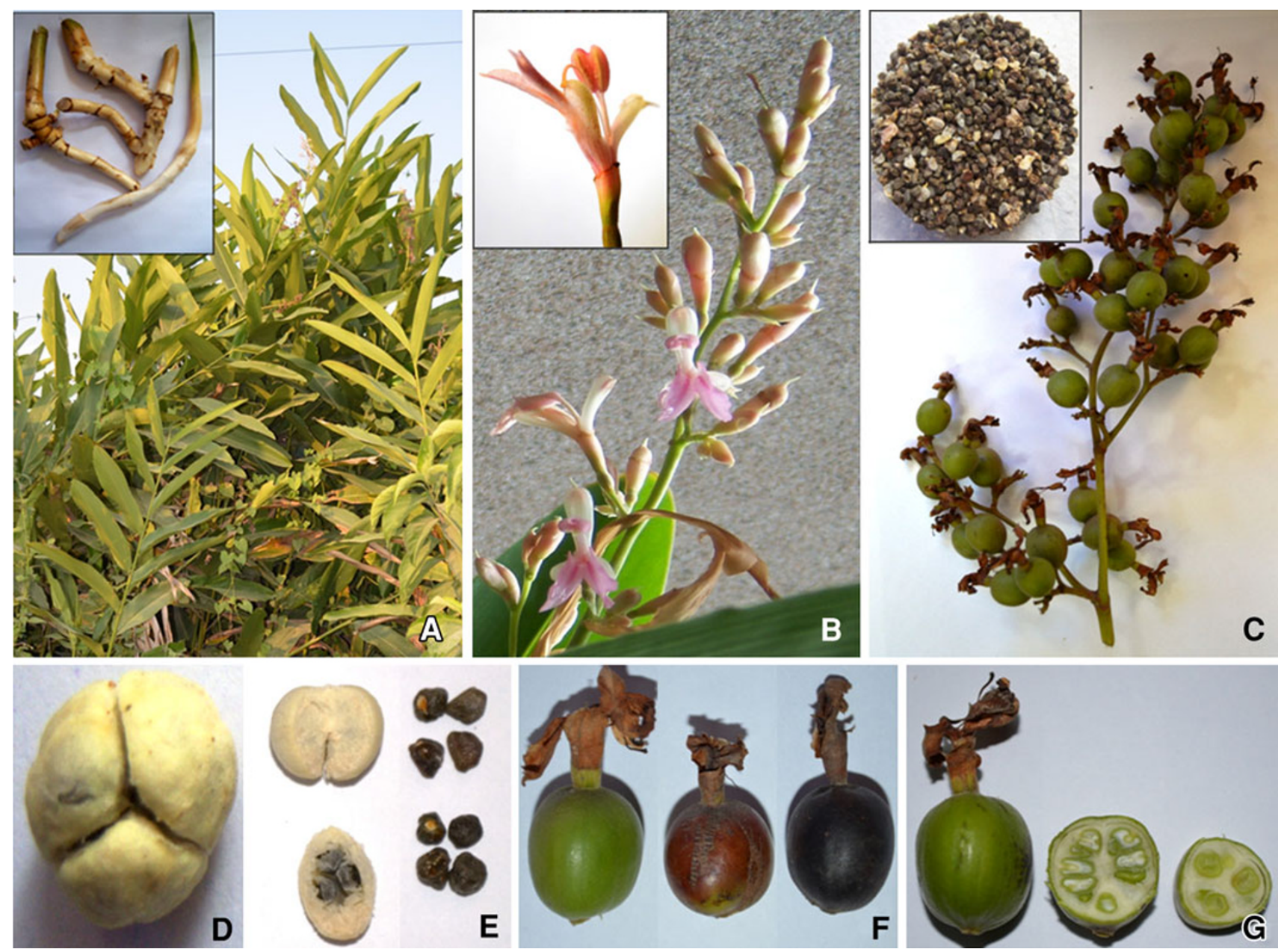

Fig. 1 Different plant parts of A. nigra used to extract bioactive compounds. a Alternate phyllotaxy of plants, inset depicts the stolon type of rhizome; $\mathbf{b}$ racemose type of inflorescence, inset shows single flower,

c developing fruit cluster, inset shows mature seeds, $\mathbf{d}$ pulpy dehusked fruit (trilocular), e locules and mature seeds, $\mathbf{f}$ different stages of fruit maturity and $\mathbf{g}$ longitudinal and cross-sectional view of the immature fruit

outer membrane integrity (Oonmetta-aree et al. 2006). However, the galangal extract, being hydrophobic in nature, could not inhibit the proliferation of gram-negative bacteria as the extract unable to penetrate the lipopolysaccharide monolayer of outer membrane of the cell wall. Terpinen-4-ol, a monoterpene, purified from the essential oil of fresh galangal rhizomes, showed antimicrobial activity against Trichophyton mentagrophytes. Similarly, acetoxychavicol acetate (ACA) isolated from dried rhizomes of A. galanga, is potentially active against several bacteria and many dermatophytes (Janssen and Scheffer 1985).

Besides the A. galanga, other species, viz. A. oxyphylla, A. speciosa, A. zerumbet and many others are gaining attention due to the presence of diverse polyphenolic compounds and their complex chemical profile. Various studies showed the antimicrobial potential of crude ethanolic extract, chloroform extract, hydrodistillation extract and a number of purified compounds against a wide spectrum of microorganism (Table 2). Moreover, recent findings showed antiviral potential of diarylheptanoid from A. katsumadai seeds. The extracts showed in vitro neuraminidase inhibitory activities against human influenza virus A/PR/8/34 of subtype H1N1 (Grienke et al. 2010). Further, different fractions of ethanolic extract were found promising against A/Chicken/Korea/MS96/96 (H9N2) influenza viruses operated by inhibiting viral hemagglutinin binding to the sialic acid receptors in the host cell (Kwon et al. 2010). The significant antimicrobial activities of different fractions and pure components of Alpinia species are catalogued in Table 2 .

Antiparasitic and insecticidal activity

Many parasites and insects pose severe threat to human and animal health. A number of medicinally important plants were tested towards their potential as an antiamoebic agent and it was found that the chloroform extracts from A. galanga to be highly effective with an added desired

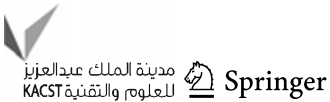


Table 1 List of prospective pharmacologically important bioactive compounds isolated from different species of Alpinia

\begin{tabular}{llll}
\hline Species name & $\begin{array}{l}\text { Plant parts } \\
\text { used }\end{array}$ & $\begin{array}{l}\text { Structure and name } \\
\text { of the compounds }\end{array}$ & Bioactivities \\
\hline A. galanga & Rhizome & Janssen and Scheffer & (1985)
\end{tabular}

Acetoxychavicol Acetate
A. mutica
Rhizome<smiles>COc1cc(O)c(C(=O)/C=C/c2ccccc2)c(O)c1</smiles>

Anticancer

Malek et al. (2011)

Pinostrobin chalcone

\section{A. katsumadai}

Seeds<smiles>CC(C)C1C=CC2(C)Oc3c(C(=O)/C=C/c4ccccc4)c(O)cc(O)c3C2C1</smiles>

Sumadain C

A. galanga

Rhizome<smiles>O=C/C=C/c1ccc(O)cc1</smiles>
p-hydroxycinnaldehyde

A. oxyphylla

Kernels<smiles>O=C(O)c1ccc(O)c(O)c1</smiles>

Protocatechuic acid

A. conchigera<smiles>COc1cc(O)cc(O)c1C(=O)/C=C/c1ccccc1</smiles>

A. officinarum

Rhizome<smiles>O=C(/C=C/CCc1ccc(O)c(O[C@H](O)CCc2ccccc2)c1)CCc1ccccc1</smiles>

Antiinflammatory

Yadav et al. (2003)

Diarylheptanoid 
Table 1 continued

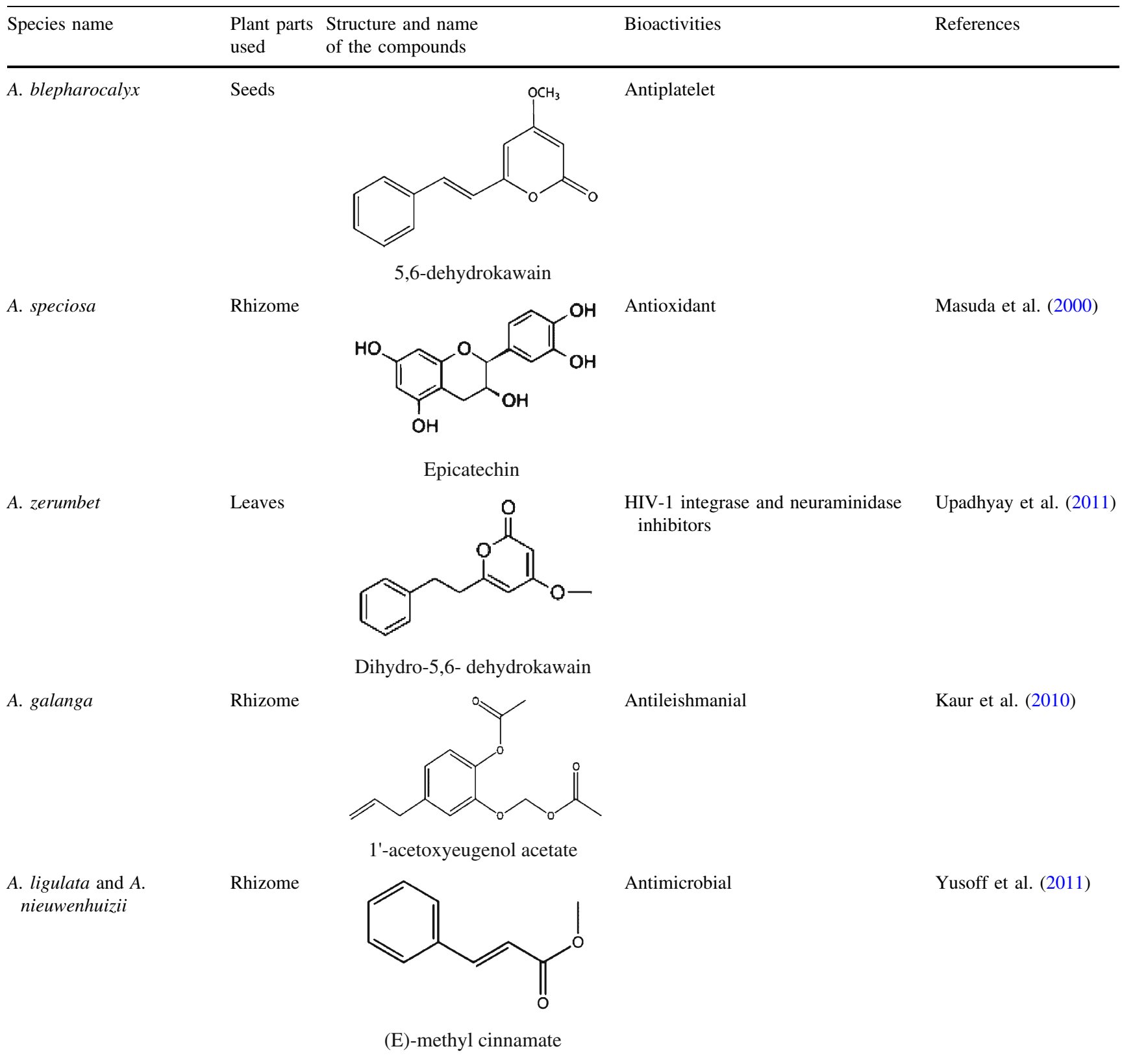

advantage of less side effects than traditional medicine, viz. metronidazole (Sawangjaroen et al. 2006). Miyazawa et al. (2000) reported that methanolic extract of A. oxyphylla was found to possess insecticidal activity against larvae of Drosophila melanogaster Meigen. From the crude extract, an insecticidal compound was separated by bioassayguided fractionation and identified to be nootkatone by GC, GC-MS, and 1H and 13C NMR spectroscopy.
Further, bioassay-guided studies for insecticidal activity, nootkatone showed a LC50 value of $11.5 \mu \mathrm{mol} / \mathrm{mL}$ of diet against larvae of $D$. melanogaster and a LD50 value of $96 \mu \mathrm{g} / \mathrm{L}$ against adults. Another compound, epinootkatol, however, showed moderate insecticidal activity in both assays, indicating that the carbonyl group at the 2-position in nootkatone was important for enhanced insecticidal activity (Fig. 3). 


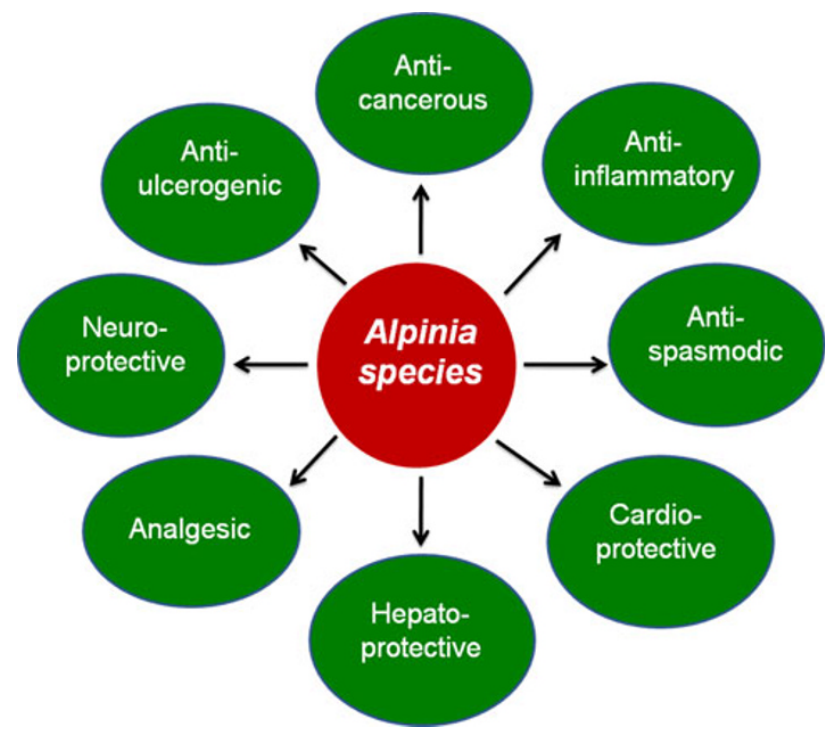

Fig. 2 Diverse biomedical application of Alpinia species

Recently, for the first time antileishmanial phenylpropanoids has been isolated using hexane, chloroform and ethyl acetate extracts of $A$. galanga rhizome (Kaur et al. 2010). Among several compounds purified, $p$-coumaryl diacetate, 1'-acetoxychavicol acetate, 1'-acetoxyeugenol acetate and trans-p-acetoxycinnamyl alcohol were found most promising in vitro against promastigotes of $L$. donovani with IC50 values of 39.3, 32.9, 18.9 and $79.9 \mu \mathrm{M}$, respectively. The genus, Alpinia harbour prospective compounds towards the antiparastic and insecticidal actions as enlisted in Table 2 .

\section{Anticancerous activity}

Many in vitro studies that have been done in diverse cancer cell lines and in vivo studies with animal models reflect clearly the potential of Alpinia species as anticancerous plant. For instance, a novel compound, Pinostrobin chalcone, has been isolated from A. mutica which displays notable cytotoxic potential to various human carcinoma cell lines (KB, MCF7 and Caski cells) with significant IC50 values (Malek et al.2011). Antiangiogenic potential of A. oxyphylla fruits has been found in $n$-hexane and ethyl acetate fractions and tested against zebrafish model, human umbilical vein endothelial cells and tumour cell lines and have been hypothesized against cancer and inflammation diseases (He et al. 2010). Investigation of Nam et al. (2005) on the $n$-hexane and chloroform extract of $A$. galanga rhizome lead to the isolation of two compounds, viz. $1^{\prime}-(S)-1^{\prime}$-acetoxychavicol acetate and $p$-coumaryl alcohol $\gamma$ - $O$-methyl ether. Of the two compounds, former showed significant cytotoxic activity against human cancer cell lines like A549 $($ IC50 $=8.14 \mu \mathrm{g} / \mathrm{mL}), \quad$ SNU638 $\quad($ IC50 $=1.27 \mu \mathrm{g} / \mathrm{mL})$,
HT1080 $($ IC50 $=1.2 \mu \mathrm{g} / \mathrm{mL}), \mathrm{HL} 60(\mathrm{IC} 50=2.39 \mu \mathrm{g} / \mathrm{mL})$ and HCT116 $(\mathrm{IC} 50=1.77 \mu \mathrm{g} / \mathrm{mL})$. Whereas, the second compound revealed specific activity against SNU638 $($ IC50 $=1.62 \mu \mathrm{g} / \mathrm{mL})$. In some other cancer cell lines cytotoxic activity has been screened with four different compounds isolated from A. officinarum and only 7-(3,4dihydroxyphenyl)-1-(4-hydroxy-3-methoxyphenyl)-4-en3-heptanone was found remarkable cytotoxic agent against HepG2, MCF-7 and SF-268 (An et al. 2008).

Lu et al. (2007) studied the effect of flavonoid constituents of A. officinarum on whitening effects based on melanin biosynthesis in B 16 mouse melanoma cells. The flavonoid mixture and galangin exhibited a broad absorption band at $270-290 \mathrm{~nm}$ related to the UV-B area supporting that galangin could be a whitening agent and a capable candidate for prevention of skin cancer. The summarized anticancerous activities of the crude extract and isolated principal compounds of the genus Alpinia are listed in Table 3.

\section{Antiinflammatory and analgesic activity}

Inflammation is a protective response by the organism to eliminate the injurious stimuli and to initiate the healing process. It's a complex biological response of vascular tissues to detrimental stimuli such as pathogens, injured cells or external irritants (Ferrero-Miliani et al. 2007). Therefore, antiinflammatory drugs refer to the property of a substance that trims down inflammation. Antiinflammatory drugs reduce inflammation without affecting the central nervous system and make up about half of analgesics available in the market. Medication towards inflammation depends on steroids, non-steroidal antiinflammatory drugs (NSAID), immune selective antiinflammatory derivatives (ImSAIDs) and herbal drugs. However, inhibitions of natural hormones and liver dysfunction are the common side effects of steroidal drugs (Urhausen et al. 2003; Hartgens et al. 1996). Similarly, NSAID can cause gastric erosions, leading to stomach ulcers and in extreme cases can cause severe haemorrhage, resulting in death by myocardial infarction and stroke (Trelle et al. 2011). Therefore, ImSAIDs and herbal drugs are more acceptable to treat inflammation and remedying pain. There are several bioactive compounds that have been isolated from Alpinia species which shows antiinflammatory and analgesic actions.

Natural bioactive compounds and crude hydroalcoholic fractions isolated from the Alpinia species like A. galanga, A. zerumbet, A. officinarum, etc., showed potential activities as antiinflammatory and analgesic agent. Aqueous and hydroalcoholic extracts from leaves and rhizomes of above species possesses key factors responsible for antinociceptive (reducing sensitivity to painful stimuli) and antiallergic 
Table 2 List of antimicrobial, antiparasitic and insecticidal actions of bioactive fractions and pure compounds of Alpinia species

\begin{tabular}{|c|c|c|c|c|}
\hline Species name & Parts used & Bioactive fractions/compounds & Bioactivity & References \\
\hline A. galanga & Rhizome & Acetoxychavicol acetate & Antifungal & $\begin{array}{l}\text { Janssen and Scheffer } \\
\text { (1985) }\end{array}$ \\
\hline A. katsumadai & Seeds & Ethanol extract and fractions & Antiviral & Kwon et al. (2010) \\
\hline A. conchigera & $\begin{array}{l}\text { Leaves, stem and } \\
\text { rhizomes }\end{array}$ & $\begin{array}{l}\text { Essential oil obtained from } \\
\text { hydrodistillation }\end{array}$ & $\begin{array}{l}\text { Antibacterial and } \\
\text { antifungal }\end{array}$ & Ibrahima et al. (2009) \\
\hline A. galanga & Rhizome & D,L-1-Acetoxychavicol acetate & Antimicrobial & $\begin{array}{l}\text { Oonmetta-aree et al. } \\
\text { (2006) }\end{array}$ \\
\hline A. galanga & Rhizome & Ethanol extract & Antimicrobial & Khattak et al. (2005) \\
\hline A. galanga & Rhizome & Chloroform extract & Antigiardial & $\begin{array}{l}\text { Sawangjaroen et al. } \\
\text { (2005) }\end{array}$ \\
\hline A. speciosa & Leaves & Ethanol extract & Antimicrobial & $\begin{array}{l}\text { Wang and Huang } \\
\text { (2005) }\end{array}$ \\
\hline A. calcarata & Rhizome & Hydrodistilled essential oil & Antifungal & Lakshmi et al. (2010) \\
\hline A. galanga & Rhizome & Ethanolic extract & Antidermatophytic & $\begin{array}{l}\text { Trakranrungsie et al. } \\
\text { (2008) }\end{array}$ \\
\hline A. speciosa & Leaves & 5,6-Dehydrokawain derivatives & Antifungal & Tawata et al. (1996) \\
\hline $\begin{array}{l}\text { A. ligulata and } \\
\text { A. nieuwenhuizii }\end{array}$ & Rhizome & Essential oil & $\begin{array}{l}\text { Antibacterial and } \\
\text { antifungal }\end{array}$ & Yusoff et al. (2011) \\
\hline A. pahangensis & Leaves and rhizomes & Hydrodistilled essential oil & Antibacterial & Awang et al. (2011) \\
\hline A. galanga & Rhizome & $1^{\prime}$-Acetoxy-chavicol acetate & Antibacterial & $\begin{array}{l}\text { Weerakkody et al. } \\
\text { (2011) }\end{array}$ \\
\hline A. galanga & Leaves and rhizomes & $\begin{array}{l}\text { Methanol, acetone and diethyl ether } \\
\text { extracts }\end{array}$ & Antibacterial & Rao et al. (2010) \\
\hline A. galanga & Rhizome & $\begin{array}{l}\text { Ethyl acetate extract ( } 1^{\prime} \text {-acetoxychavicol } \\
\text { acetate) }\end{array}$ & Protects acne & Niyomkam et al. (2010) \\
\hline A. galanga & Rhizome & Chloroform extracts & Antifungal & $\begin{array}{l}\text { Phongpaichit et al. } \\
\text { (2005) }\end{array}$ \\
\hline A. galanga & Rhizome & Ethanolic extract & Antifungal & Ficker et al. (2003) \\
\hline A. galanga & Rhizome & Chloroform extract & Antiamoebic & $\begin{array}{l}\text { Sawangjaroen et al. } \\
\text { (2006) }\end{array}$ \\
\hline A. nigra & Shoots & Crude aqueous extract & Flukicidal & $\begin{array}{l}\text { Roy and Tandon } \\
\text { (1999) }\end{array}$ \\
\hline A. galanga & Rhizome & Methanol extract & Antimalarial & Abdulelah et al. (2010) \\
\hline A. nigra & Shoots & Ethanolic extract & Anthelmintic & $\begin{array}{l}\text { Roy and Swargiary } \\
\text { (2009) }\end{array}$ \\
\hline A. galanga & Rhizome & $\begin{array}{l}\text { Hexane, chloroform and ethyl acetate } \\
\text { extract }\end{array}$ & Antileishmanial & Kaur et al. (2010) \\
\hline A. galanga & Rhizome & $\begin{array}{l}\text { Hexane, dichloromethane, ethyl acetate } \\
\text { and ethanol }\end{array}$ & Insecticidal & Sukhirun et al. (2010) \\
\hline A. oxyphylla & Fruits & Methanol extract, yakuchinone A (1) & Insecticidal & Miyazawa et al. (2001) \\
\hline A. oxyphylla & Fruits & Nootkatone & Insecticidal & Miyazawa et al. (2000) \\
\hline A. purpurata & Flowers & Essential oils and aqueous extracts & $\begin{array}{l}\text { Larvicidal and } \\
\text { antibacterial }\end{array}$ & Santos et al. (2012) \\
\hline
\end{tabular}

properties. Diarylheptanoids, a novel class of potent plateletactivating factor (PAF) antagonists from A. officinarum rhizome extract was recently identified (Fan et al. 2007), which also showed antirheumatic, antipsychiatric and analgesic activities with $80 \%$ ethanolic extract (Lee et al. 2009). A brief account of the antiinflammatory, analgesic and other related activities of Alpinia are listed in Table 3.
Neuroprotective activity

A. galanga has been exhaustively explored towards diverse biological activities in most of the cases among different Alpinia species. Recently, chloroform fraction of A. galanga has been found as antiamnesic probably due to the presence of $1^{\prime} S-1^{\prime}$-acetoxyeuginol acetate as lead 


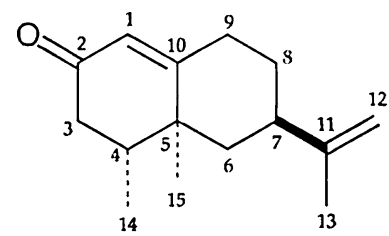

Nootkatone

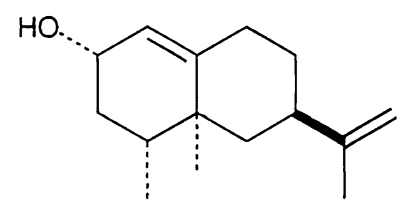

Epinootkatol
Fig. 3 The structure of Nootkatone and Epinootkatol isolated from A. oxyphylla fruits, where they differ on their 2-position due to the presence of carbonyl $(-\mathrm{C}=\mathrm{O})$ and aldehyde $(-\mathrm{CHO})$ group, respectively

compound (Singh et al. 2011a). A. oxyphylla fruit was found to have the neuroprotective activities (Koo et al. 2004) and subsequently many other Alpinia species have been reported since (Table 4). Protocatechuic acid (PCA), a principal compound of the A. oxyphylla, protects against oxidative damage in vitro and reduces oxidative stress in vivo (Shi et al. 2006). It has been shown that PCA also reduces the hydrogen peroxide or sodium nitroprusside induced cell death in PC12 cells in dose-dependent manner (An et al. 2006) and this offers a valuable therapeutic strategy for the cure of oxidative stress-induced neurodegenerative disease like Parkinson's disease. Other reports revealed that $A$. katsumadai seed extract protects neurons from ischaemic damage (Li et al. 2011a) and the treatment significantly decreased the activation of astrocytes and microglia in the hippocampal CA1 region (Li et al. 2011b). Similarly, methanolic extract of $A$. officinarum rhizome

Table 3 List of anticancerous, antiinflammatory and analgesic activities showed by bioactive fractions and major compounds from Alpinia species

\begin{tabular}{|c|c|c|c|c|}
\hline Species name & $\begin{array}{l}\text { Parts } \\
\text { used }\end{array}$ & Bioactive fractions/compounds & Bioactivity & References \\
\hline A. galanga & Rhizome & $\begin{array}{l}1^{\prime} S \text {-1'-Acetoxychavicol acetate and } \\
p \text {-coumaryl alcohol } \gamma \text { - } O \text {-methyl ether }\end{array}$ & Anticancerous & Nam et al. (2005) \\
\hline A. officinarum & Rhizome & $\begin{array}{l}\text { 7-(3,4-Dihydroxyphenyl)-1-(4-hydroxy- } \\
\text { 3-methoxyphenyl)-4-en-3-heptanone }\end{array}$ & Anticancerous & An et al. (2008) \\
\hline A. pricei & Rhizome & Ethanolic extract & Apoptotic & Yang et al. (2008) \\
\hline A. oxyphylla & Fruits & Oxyphyllone A and B & Anticancerous & Xu et al. (2009) \\
\hline A. conchigera & Rhizome & $1^{\prime} S-1^{\prime}$-Acetoxychavicol acetate & Apoptotic & Awang et al. (2010) \\
\hline A. katsumadai & Seeds & Rubraine, isorubraine and sumadain & Anticancerous & Hua et al. (2009) \\
\hline A. scabra & $\begin{array}{l}\text { Leaves and } \\
\text { rhizome }\end{array}$ & Hexane and dicholoromethane extract & Anticancerous & Ibrahim et al. (2010) \\
\hline A. oxyphylla & Fruits & Hexane and ethyl acetate fractions & Antiangiogenic & He et al. (2010) \\
\hline A. mutica & Rhizome & Pinostrobin & Anticancerous & Malek et al. (2011) \\
\hline A. officinarum & Rhizome & Galangin & Prevents skin cancer & Lu et al. (2007) \\
\hline A. blepharocalyx & Seeds & Diarylheptanoids & Antiproliferative & Ali et al. (2001) \\
\hline A. calcarata & Rhizome & Aqueous and ethanolic extract & Antinociceptive & $\begin{array}{l}\text { Arambewela et al. } \\
\text { (2004) }\end{array}$ \\
\hline A. officinarum & Rhizome & Ethanolic extract & $\begin{array}{l}\text { Antinociceptive, } \\
\text { antiinflammatory, and } \\
\text { antipsychiatric }\end{array}$ & Lee et al. (2009) \\
\hline A. officinarum & Rhizome & $\begin{array}{l}\text { Hydroxy-1,7-diphenyl-4-en-3-heptanone } \\
\text { 6, 6-(2-hydroxy-phenyl)-4-methoxy-2-pyrone, } \\
\text { 1,7-diphenyl-4-en-3-heptanone, 1,7-diphenyl- } \\
\text { 5-methoxy-3-heptanone and apigenin }\end{array}$ & $\begin{array}{l}\text { Platelet-activating factor } \\
\text { (PAF) antagonists }\end{array}$ & Fan et al. (2007) \\
\hline A. galangal & Rhizome & Alcoholic and aqueous extracts & Antiinflammatory & $\begin{array}{l}\text { Satish and Dhananjayan } \\
\text { (2003) }\end{array}$ \\
\hline A. conchigera & Rhizome & Cardamomin & Antiinflammatory & Lee et al. (2006) \\
\hline A. galanga & Rhizome & $\begin{array}{l}\text { 7-(4'-Hydroxy-3'-methoxyphenyl)-1- } \\
\text { phenylhept-4-en-3-one }\end{array}$ & Antiinflammatory & Yadav et al. (2003) \\
\hline A. galanga & Rhizome & $\begin{array}{l}1^{\prime} S-1^{\prime} \text {-acetoxychavicol acetate and } \\
1^{\prime} S \text {-1'-acetoxyeugenol acetate }\end{array}$ & Antiallergic & Matsuda et al. (2003a, b) \\
\hline A. galanga & Rhizome & Acetoxybenzhydrols & Antiallergic & Yasuharaa et al. (2009) \\
\hline A. pricei & Rhizome & $70 \%$ Ethanolic extract & Antiinflammatory & Yu et al. (2009) \\
\hline A. pricei & Rhizome & Flavokawain B & Antiinflammatory & Lin et al. (2009) \\
\hline
\end{tabular}


Table 4 List of neuroprotective and antioxidant activities exhibited by various natural bioactive compounds and crude fractions of Alpinia species

\begin{tabular}{|c|c|c|c|c|}
\hline Species name & Parts used & Bioactive fractions/compounds & Bioactivity & References \\
\hline A. oxyphylla & Fruits & Ethanolic extract & Neuroprotective & Yu et al. (2003) \\
\hline A. oxyphylla & Fruits & Protocatechuic acid & Neuroprotective & Shi et al. (2006) \\
\hline A. oxyphylla & Kernel & Protocatechuic acid & Neuroprotective & An et al. (2006) \\
\hline A. officinarum & Rhizome & Methanolic extract & Neuroprotective & Chang et al. (2011) \\
\hline A. katsumadai & Seeds & $70 \%$ Ethanolic extract & Neuroprotective & Li et al. (2011a) \\
\hline A. katsumadai & Seeds & Ethanolic extract & Neuroprotective & Li et al. (2011b) \\
\hline A. oxyphylla & Fruits & $80 \%$ Ethanolic extract & Neuroprotective & Zhang et al. (2011b) \\
\hline A. oxyphylla & Fruits & Water extract & Neuroprotective & Koo et al. (2004) \\
\hline A. oxyphylla & Fruits & $94 \%$ Ethanolic extract & Neuroprotective & Yu et al. (2003) \\
\hline A. galanga & Rhizome & $n$-Hexane, chloroform and ethyl acetate & Neuroprotective & Singh et al. (2011a) \\
\hline A. galanga & Rhizome & Ethanolic extract & Neuroprotective & Singh et al. (2011b) \\
\hline A. zerumbet & $\begin{array}{l}\text { Leaves and } \\
\text { rhizome }\end{array}$ & $\begin{array}{l}\text { Dihydro-5,6-dehydrokawain and other ethyl } \\
\text { acetate and hexane extract }\end{array}$ & Antioxidant & $\begin{array}{l}\text { Elzaawely et al. } \\
\text { (2007b) }\end{array}$ \\
\hline A. zerumbet & Flowers and seeds & Ethyl acetate and hexane extract & Antioxidant & $\begin{array}{l}\text { Elzaawely et al. } \\
\text { (2007a) }\end{array}$ \\
\hline $\begin{array}{l}\text { A. galanga and } \\
\text { A. allughas }\end{array}$ & Rhizome & Dichloromethane and methanol extract & Antioxidant & Vankar et al. (2006) \\
\hline A. speciosa & Rhizome & Feruloyl esters with epicatechin & Antioxidant & Masuda et al. (2000) \\
\hline A. katsumadai & Seeds & $\begin{array}{l}\text { Epigallocatechine-3-gallate, resveratrol and } \\
\text { total extract }\end{array}$ & Antioxidant & Lee et al. (2003) \\
\hline A. officinarum & Rhizome & Methanolic extract & Antioxidant & Chang et al. (2011) \\
\hline A. calcarata & Rhizome & $\begin{array}{l}\text { Hydrodistilled n-pentane and } \\
\text { ether extract }\end{array}$ & Antioxidant & $\begin{array}{l}\text { Arambewela et al. } \\
\text { (2010) }\end{array}$ \\
\hline A. oxyphylla & Fruits & Protocatechuic acid & Antioxidant & Zhang et al. (2011a) \\
\hline A. galanga & Rhizome & Ethanol extract & Antioxidant & Singh et al. (2011b) \\
\hline A. densespicata & Stem and leaves & Ethanol extract & $\begin{array}{l}\text { Nitric oxide } \\
\text { inhibitory }\end{array}$ & Kuo et al. (2009) \\
\hline A. officinarum & Rhizome & Hydro alcoholic extract & Antioxidant & $\begin{array}{l}\text { Srividya et al. } \\
\text { (2010) }\end{array}$ \\
\hline
\end{tabular}

showed protection against oxidative damage in PC 12 cells (Chang et al. 2011).

Antioxidant and other activities

Essential oil of $A$. zerumbet has strong potential as antipsychotic and antioxidant agent (de Araújo et al. 2011) which may have promising efficacy for the treatment of schizophrenia. On the other hand, A. galanga ethanol extract shows antiamnesiac effect in Amyloid $\beta$ induced neurodegeneration (Singh et al. 2011b). Members of the Alpinia genus are found to have a remarkable antioxidant activity which in turn gives more biological efficacy towards the development of therapeutics. The antioxidant activities of the genus are enlisted in Table 4.

Besides above activities, the genus is also emerging as the prospective source for antiageing compound which is found to be PCA from A. oxyphylla (Zhang et al. 2011a). Aqueous acetone extract of $A$. officinarum rhizome showed inhibition to melanogenesis process (Matsuda et al. 2009), whereas acetone extract of A. oxyphylla fruits acts as a potent skin permeation enhancer (Fang et al. 2003). Recent studies revealed two bioactive compounds from $A$. zerumbet rhizome and leaves, viz. 5,6-dehydrokawain (DK) and dihydro-5,6-dehydrokawain (DDK). The compounds were found to be potent inhibitor of HIV-1 integrase and neuraminidase (Upadhyay et al. 2011) indicating that it could be used as potent drugs against those viral diseases.

\section{Future perspective and consideration}

In the current study, it has been observed that various plant parts of different Alpinia species are used to get the 


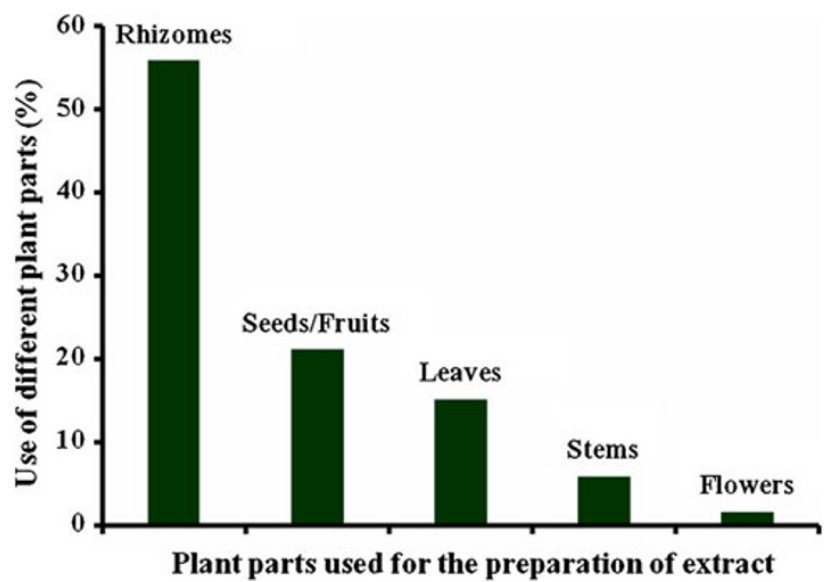

Fig. 4 The graph represents the use of various plant parts in terms of percent use towards the versatile bioactivity studies under consideration in the current review

bioactive compounds and different fractions show remarkable biological efficacy against various biomedical challenges. Detailed examination of the gathered data in Alpinia shows that rhizome is the main plant part used for pharmacological investigation, whereas other vegetative and reproductive parts were used moderately (Fig. 4). Most of the cases it has been observed that rhizomes harbour most of the essential oil components and showed potential biological activities at different scale. It has also been observed that various solvent systems were used in the bioactivity studies and isolation of bioactive compounds from the plant parts which acts as a key factor in terms of yield, number of compounds, type of compounds, etc. In the current study, it has been clearly observed that ethanol fraction has been the most preferred solvent system which has been used either in the initial crude oil extraction or in the further fractionation process (Fig. 5). The aqueous solvent was found to be the second best choice for the study as it also can extract copious amount of essential oil from different plant parts, but it varies from species to species. The bioactive compounds or crude fractions of essential oils from various species of Alpinia were found to be promising against various biomedical challenges like antimicrobial, anticancerous, antileshmania and many more. Also, in the current study, it has been observed that various species of Alpinia has ample potential to overpower biomedical threats including the most diverse microbes in the mother earth. Moreover, the genus Alpinia harbours versatile components towards its diverse biological efficacy (Fig. 6). Much more understanding and further exploration will be needed towards the other unexplored species of the genus, viz. A. nigra, A. katsumadai, A. pahangensis, A. nieuwenhuizii and many more to circumvent the future biomedical challenges.

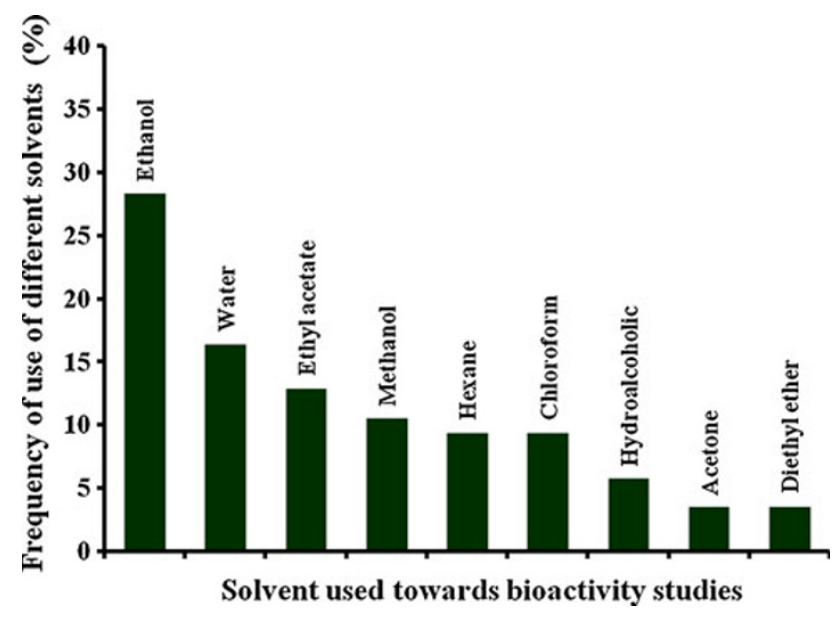

Fig. 5 Different solvent system has been used for the extraction of crude oil and bioactive components. Each bar represents the percentage of uses of each solvent towards the extraction method related to the genus Alpinia documented under current study

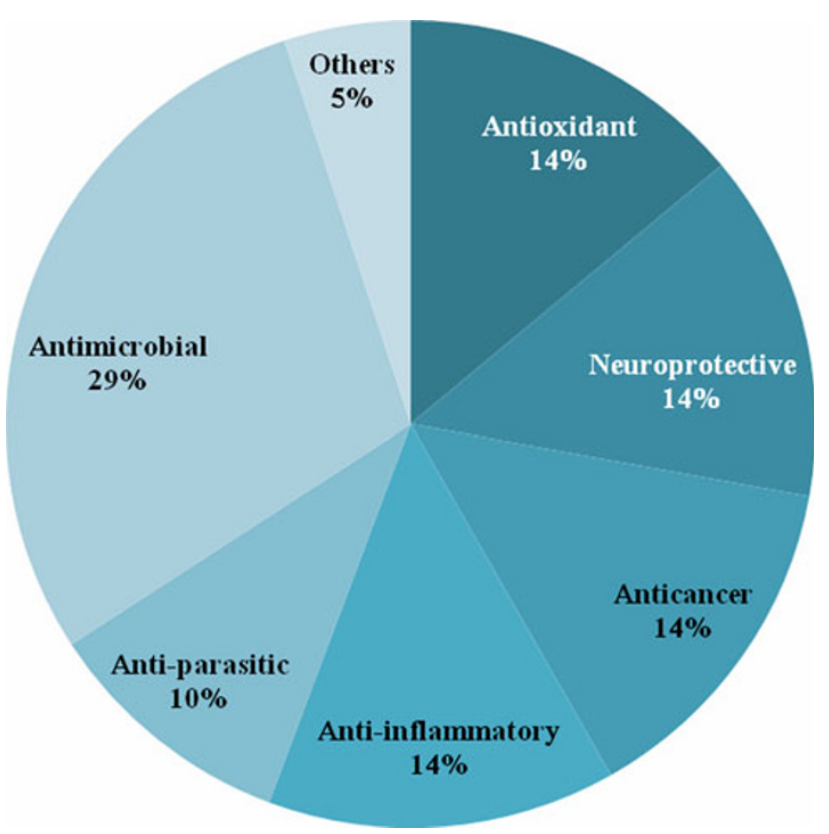

Fig. 6 The potential application and research carried out in various field of biomedical sciences related to the genus Alpinia and expressed in terms of percentage biological activities considered under the current study

\section{Conclusion}

Detailed account of the diverse utility of the genus Alpinia can be addressed, starting with the ethnomedicinal information culminating with exhaustive scientific exploration. Towards the pharmacological investigation and future diagnostics, drug designing and modulating different transregulating pathways will be useful to fight against the deadly diseases prevalent in the earth. During the current 
study, it has been found that the genus possess plenty of flavonoids, tannin and other polyphenolics which extends its biological efficacy towards antiinflammatory, antimicrobial, anticancerous and other therapeutic potentials. It was found in most of the reports and reviews that were surveyed in the present investigation, the crude extract (aqueous or organic fractions) to be potential agent for various activities. However, thorough examination needs to be carried out to see the efficacy and activity of individual component and in combination to explore the synergistic effects, if any.

Acknowledgments Thanks to Department of Information Technology (DIT), Ministry of Information Technology, Government of India for student fellowship to SG and for research grant to LR (DIT Grant No. DIT No: 0526/T/IITG/014/0809/38).

Open Access This article is distributed under the terms of the Creative Commons Attribution License which permits any use, distribution, and reproduction in any medium, provided the original author(s) and the source are credited.

\section{References}

Abdulelah HA, Zurainee MN, Hesham MAM, Mahmud R, Dose ML (2010) Antimalarial activity, phytochemical screening and radical scavenging of methanolic Languas galanga rhizome extract. Molecules 15:8366-8376

Ali MS, Banskota AH, Tezuka Y, Saiki I, Kadota S (2001) Antiproliferative activity of diarylheptanoids from the seeds of Alpinia blepharocalyx. Biol Pharm Bull 24(5):525-528

An LJ, Guan S, Shi GF, Bao YM, Duan YL, Jiang B (2006) Protocatechuic acid from Alpinia oxyphylla against $\mathrm{MPP}^{+}$-induced neurotoxicity in PC12 cells. Food Chem Toxicol 44:436-443

An N, Zou Z, Tian Z, Luo XZ, Yang S, Xu LZ (2008) Diarylheptanoids from the rhizomes of Alpinia officinarum and their anticancer activity. Fitoterapia 79:27-31

Arambewela LSR, Arawwawala LDAM, Ratnasooriya WD (2004) Antinociceptive activities of aqueous and ethanolic extracts of Alpinia calcarata rhizomes in rats. J Ethnopharmacol 95:311-316

Arambewela LS, Arawwawala LD, Athauda N (2010) Antioxidant and antifungal activities of essential oil of Alpinia calcarata Roscoe rhizomes. J Ayurveda Integr Med 1(3):199-202

Awang K, Azmi MN, Aun LIL, Aziz AN, Ibrahim H, Nagoor NH (2010) The apoptotic effect of $1^{\prime} \mathrm{S}-1^{\prime}$-acetoxychavicol acetate from Alpinia conchigera on human cancer cells. Molecules 15:8048-8059

Awang K, Ibrahim H, Rosmy Syamsir D, Mohtar M, Mat Ali R, Azah Mohamad Ali N (2011) Chemical constituents and antimicrobial activity of the leaf and rhizome oils of Alpinia pahangensis Ridl., an endemic wild ginger from peninsular Malaysia. Chem Biodivers 8(4):668-673

Chang CL, Lin CS, Lai GH (2011) Phytochemical characteristics, free radical scavenging activities, and neuroprotection of five medicinal plant extracts. Evid Based Complement Alternat Med. doi:10.1155/2012/984295

de Araújo FY, de Oliveira GV, Gomes PX, Soares MA, Silva MI, Carvalho AF, de Moraes MO, de Moraes ME, Vasconcelos SM, Viana GS, de Sousa FC, Macêdo DS (2011) Inhibition of ketamine-induced hyperlocomotion in mice by the essential oil of Alpinia zerumbet: possible involvement of an antioxidant effect. J Pharm Pharmacol 63(8):1103-1110

Elzaawely AA, Xuan TD, Tawata S (2007a) Antioxidant activity and contents of essential oil and phenolic compounds in flowers and seeds of Alpinia zerumbet (Pers.) B.L. Burtt. \& R.M. Sm. Food Chem 104:1648-1653

Elzaawely AA, Xuan TD, Tawata S (2007b) Essential oils, kava pyrones and phenolic compounds from leaves and rhizomes of Alpinia zerumbet (Pers.) B.L. Burtt. \& R.M. Sm. and their antioxidant activity. Food Chem 103:486-494

Fan G, Kang YH, Han YN, Han BH (2007) Platelet-activating factor (PAF) receptor binding antagonists from Alpinia offcinarum. Bioorg Med Chem Lett 17:6720-6722

Fang JY, Leu YL, Hwang TL, Cheng HC, Hung CF (2003) Development of sesquiterpenes from Alpinia oxyphylla as novel skin permeation enhancers. Eur J Pharm Sci 19:253-262

Ferrero-Miliani L, Nielsen OH, Andersen PS, Girardin SE (2007) Chronic inflammation: importance of NOD2 and NALP3 in interleukin-1beta generation. Clin Exp Immunol 147(2):227-235

Ficker CE, Smith ML, Susiarti S, Leaman DJ, Irawati C, Arnason JT (2003) Inhibition of human pathogenic fungi by members of Zingiberaceae used by the Kenyah (Indonesian Borneo). J Ethnopharmacol 85(2-3):289-293

Ghasi S, Nwobodo E, Ofili JO (2000) Hypocholesterolemic effect of crude leaf of Moringa oleifera in high fat diet fed wistar rats. J Ethnopharmacol 69:21-25

Grienke U, Schmidtke M, Kirchmair J, Pfarr K, Wutzler P, Dürrwald R, Wolber G, Liedl KR, Stuppner H, Rollinger JM (2010) Antiviral potential and molecular insight into neuraminidase inhibiting diarylheptanoids from Alpinia katsumadai. J Med Chem 53:778-786

Hartgens F, Kuipers H, Wijnen JA, Keizer HA (1996) Body composition, cardiovascular risk factors and liver function in long-term androgenic-anabolic steroids using bodybuilders three months after drug withdrawal. Int J Sports Med 17(6):429433

He ZH, Ge W, Yue GGL, Lau CBS, He MF, But PPH (2010) Antiangiogenic effects of the fruit of Alpinia oxyphylla. J Ethnopharmacol 132:443-449

Hua SZ, Luo JG, Wang XB, Wang JS, Kong LY (2009) Two novel monoterpene-chalcone conjugates isolated from the seeds of Alpinia katsumadai. Bioorg Med Chem Lett 19:2728-2730

Ibrahim H, Sim KS, Syamsir DR, Nor NRM, Nurestri AMS, Awang K (2010) Cytotoxic activity of leaf and rhizome extracts of Alpinia scabra (Blume) Náves, a wild ginger from Peninsular Malaysia. Afr J Pharm Pharmacol 4(10):708-711

Ibrahima H, Aziz AN, Syamsir DR, Ali NAM, Mohtar M, Ali RM, Awang K (2009) Essential oils of Alpinia conchigera Griff. and their antimicrobial activities. Food Chem 113:575-577

Jain SK, Prakash V (1995) 22 genera and 178 species in India concentrated mainly in North eastern and the Peninsular region (Zingiberaceae in India) Phytogeography and endemism. Rheedea 5(2):154-169

Janssen AM, Scheffer JJC (1985) Acetoxychavicol acetate, an antifungal component of Alpinia galanga. Planta Med 6:507511

Kaur A, Singh R, Dey CS, Sharma SS, Bhutani KK, Singh IP (2010) Antileishmanial phenylpropanoids from Alpinia galanga (Linn.) Willd. Ind J Exp Biol 48:314-317

Khattak S, Rehman S, Shah HU, Ahmad W, Ahmad M (2005) Biological effects of indigenous medicinal plants Curcuma longa and Alpinia galanga. Fitoterapia 76:254-257

Koo BS, Lee WC, Chang YC, Kim CH (2004) Protective effects of Alpina oxyphylla fructus (Alpinia oxyphylla MIQ) water-extracts on neurons from ischemic damage and neuronal cell toxicity. Phytother Res 8(2):142-148

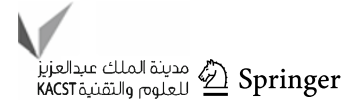


Kress WJ, Liu AZ, Newman M, Li QJ (2005) The molecular phylogeny of Alpinia (Zingiberaceae): a complex and polyphyletic genus of gingers. Am J Bot 92:167-178

Kuo YJ, Hsiao PC, Zhang LJ, Wu MD, Liang YH, Ho HO, Kuo YH (2009) Labdane diterpenoid glycosides from Alpinia densespicata and their nitric oxide inhibitory activities in macrophages. J Nat Prod 72(6):1097-1101

Kwon HJ, Kim HH, Yoon SY, Ryu YB, Chang JS, Cho KO, Rho MC, Park SJ, Lee WS (2010) In vitro inhibitory activity of Alpinia katsumadai extracts against influenza virus infection and hemagglutination. Virol J 7:307

Lakshmi SR, Arambewela LDA, Arawwawala M, Athauda N (2010) Antioxidant and antifungal activities ofessential oil of Alpinia calcarata Roscoe rhizomes. J Ayurveda Integr Med 1(3):199-202

Lee SE, Shin HT, Hwang HJ, Kim JH (2003) Antioxidant activity of extracts from Alpinia katsumadai seed. Phytother Res 7(9): 1041-1047

Lee JH, Jung HS, Giang PM, Jin X, Lee S, Son PT, Lee D, Hong YS, Lee K, Lee JJ (2006) Blockade of nuclear factor-kB signaling pathway and anti-inflammatory activity of Cardamomin, a chalcone analog from Alpinia conchigera. J Pharmacol Exp Ther 316:271-278

Lee JS, Kim KA, Jeong SH, Lee SG, Park HJ, Kim NJ, Lim S (2009) Anti-inflammatory, anti-nociceptive, and anti-psychiatric effects by the rhizomes of Alpinia officinarum on complete Freund's adjuvant-induced arthritis in rats. J Ethnopharmacol 126:258264

Li H, Park JH, Yan B, Yoo KY, Lee CH, Choi JH, Hwang IK, Won MH (2011a) Neuroprotection of Alpinia katsumadai seed extract against neuronal damage in the ischemic gerbil hippocampus is linked to altered brain-derived neurotrophic factor. Lab Anim Res 27(1):67-71

Li H, Yoo KY, Lee CH, Choi JH, Hwang IK, Kim JD, Kim YM, Kang IJ, Won MH (2011b) Neuroprotective effects of Alpinia katsumadai against neuronal damage in the gerbil hippocampus induced by transient cerebral ischemia. Int J Neurosci 121(9): 490-496

Lin CT, Senthil Kumar KJ, Tseng YH, Wang ZJ, Pan MY, Xiao JH, Chien SC, Wang SY (2009) Anti-inflammatory activity of Flavokawain B from Alpinia pricei Hayata. J Agric Food Chem 57(14):6060-6065

Lu YH, Lin-Tao Wang ZT, Wei DZ, Xiang HB (2007) Mechanism and inhibitory effect of galangin and its flavonoid mixture from Alpinia officinarum on mushroom tyrosinase and B16 murine melanoma cells. J Enzyme Inhib Med Chem 22(4):433-438

Malek SNA, Phang CW, Ibrahim H, Norhanom AW, Sim KS (2011) Phytochemical and cytotoxic investigations of Alpinia mutica rhizomes. Molecules 16:583-589

Masuda T, Mizuguchi S, Tanaka T, Iritani K, Takeda Y (2000) Isolation and structure determination of new antioxidative ferulic acid glucoside esters from the rhizome of Alpinia speciosa, a zingiberaceae plant used in okinawan food culture. J Agric Food Chem 48(5): 1479-1484

Matsuda H, Morikawa T, Managi H, Yoshikawa M (2003a) Antiallergic principles from Alpinia galanga: structural requirements of phenylpropanoids for inhibition of degranulation and release of TNF-alpha and IL-4 in RBL-2H3 cells. Bioorg Med Chem Lett 13(19):3197-3202

Matsuda H, Pongpiriyadacha Y, Morikawa T, Ochi M, Yoshikawa M (2003b) Gastroprotective effects of phenylpropanoids from the rhizomes of Alpinia galanga in rats: structural requirements and mode of action. Eur J Pharmacol 471(1):59-67

Matsuda H, Nakashima S, Oda Y, Nakamura S, Yoshikawa M (2009) Melanogenesis inhibitors from the rhizomes of Alpinia officinarum in B16 melanoma cells. Bioorg Med Chem 17(16):60486053
Miyazawa M, Nakamura Y, Ishikawa Y (2000) Insecticidal sesquiterpene from Alpinia oxyphylla against Drosophila melanogaster. J Agric Food Chem 48(8):3639-3641

Miyazawa M, Nakamura Y, Ishikawa Y (2001) Insecticidal diarylheptanoid from Alpinia oxyphylla against larvae of Drosophila melanogaster. Nat Prod Lett 15(1):75-79

Nam JW, Kim SJ, Han AR, Lee SK, Seo EK (2005) Cytotoxic phenylpropanoids from rhizomes of Alpinia galanga. J Appl Pharmacol 13:263-266

Niyomkam P, Kaewbumrung S, Kaewnpparat S, Panichayupakaranant P (2010) Antibacterial activity of Thai herbal extracts on acne involved microorganism. Pharm Biol 48(4):375-380

Oonmetta-aree J, Suzuki T, Gasaluck P, Eumkeb G (2006) Antimicrobial properties and action of galangal (Alpinia galanga Linn.) on Staphylococcus aureus. LWT Food Sci Technol 39:1214-1220

Phitak T, Choocheep K, Pothacharoen P, Pompimon W, Premanode B, Kongtawelert P (2009) The effects of p-hydroxycinnamaldehyde from Alpinia galanga extracts on human chondrocytes. Phytochemistry 70:237-243

Phongpaichit S, Subhadhirasakul S, Wattanapiromsakul C (2005) Antifungal activities of extracts from Thai medicinal plants against opportunistic fungal pathogens associated with AIDS patients. Mycoses 48(5):333-338

Prakash V, Mehrotra BN (1995) Zingiberaceae of north-east India: diversity and taxonomic status. In: Proceedings of the 2nd symposium on the family Zingiberaceae, pp 262-273

Pugialli HRL, Kaplan MAC, Gottilieb OR (1993) Chemotaxonomy of superorder Zingiberiflorae (sensu Dahlgren) I. Flavonoids. Acta Bot Bras 7:135-148

Rao K, Ch B, Narasu LM, Giri A (2010) Antibacterial activity of Alpinia galanga (L.) Willd crude extracts. Appl Biochem Biotechnol 162(3):871-884

Roy B, Swargiary A (2009) Anthelmintic efficacy of ethanolic shoot extract of Alpinia nigra on tegumental enzymes of Fasciolopsis buski, a giant intestinal parasite. J Parasit Dis 33:48-53

Roy B, Tandon V (1999) Flukicidal activity of Alpinia nigra against the trematode, Fasciolopsis buski, in humans. Biomed Lett 60:23-29

Santos GKN, Dutra KA, Barros RA, da Câmara CAG, Lira DD, Gusmão NB, Navarro DMAF (2012) Essential oils from Alpinia purpurata (Zingiberaceae): chemical composition, oviposition deterrence, larvicidal and antibacterial activity. Ind Crops Prod 40:254-260

Satish R, Dhananjayan R (2003) Evaluation of anti-inflammatory potential of rhizome of Alpinia galanga Linn. Biomedicine 23:91-96

Sawangjaroen N, Subhadhirasakul S, Phongpaichit S, Siripanth C, Jamjaroen K, Sawangjaroen K (2005) The in vitro anti-giardial activity of extracts from plants that are used for self-medication by AIDS patients in southern Thailand. Parasitol Res 95:17-21

Sawangjaroen N, Phongpaichit S, Subhadhirasakul S, Visutthi M, Srisuwan N, Thammapalerd N (2006) The anti-amoebic activity of some medicinal plants used by AIDS patients in southern Thailand. Parasitol Res 98:588-592

Seth SD, Sharma B (2004) Medicinal plants of India. Indian J Med Res 120:9-11

Shi GF, An LJ, Jiang B, Guan S, Bao YM (2006) Alpinia protocatechuic acid protects against oxidative damage in vitro and reduces oxidative stress in vivo. Neurosci Lett 403:206-210

Singh HJC, Alagarsamy V, Diwan PV, Kumar SS, Nisha JC, Narsimha Reddy Y (2011a) Neuroprotective effect of Alpinia galanga (L.) fractions on $\mathrm{A} \beta(25-35)$ induced amnesia in mice. J Ethnopharmacol. doi:10.1016/j.jep.2011.08.048

Singh HJC, Alagarsamy V, Sathesh Kumar S, Narsimha Reddy Y (2011b) Neurotransmitter metabolic enzymes and antioxidant status on Alzheimer's disease induced mice treated with Alpinia galanga (L.) Willd. Phytother Res. doi:10.1002/ptr.3364 
Srividya AR, Dhanabal SP, Misra VK, Suja G (2010) Antioxidant and antimicrobial activity of Alpinia officinarum. Indian J Pharm Sci 72(1):145-148

Sukhirun N, Pluempanupat W, Bullangpoti V (2010) Impact of Alpinia galanga rhizome extract on Bactrocera dorsalis population. Commun Agric Appl Biol Sci 75(3):399-403

Tawata S, Taira S, Kobamoto N, Ishihara M, Toyama S (1996) Syntheses and biological activities of dihydro-5,6-dehydrokawain derivatives. Biosci Biotechnol Biochem 60(10):1643-1645

Trakranrungsie N, Chatchawanchonteera A, Khunkitti W (2008) Ethnoveterinary study for antidermatophytic activity of Piper betle, Alpinia galanga and Allium ascalonicum extracts in vitro. Res Veterinary Sci 84:80-84

Trelle S, Reichenbach S, Wandel S, Hildebrand P, Tschannen B, Villiger PM, Egger M, Jüni P (2011) Cardiovascular safety of non-steroidal anti-inflammatory drugs: network meta-analysis. BMJ. doi:10.1136/bmj.c7086

Tushar, Basak S, Sarma GC, Rangan L (2010) Ethnomedical uses of Zingiberaceous plants of Northeast India. J Ethnopharmacol 132(1):286-296

Upadhyay A, Chompoo J, Kishimoto W, Makise T, Tawata S (2011) HIV-1 integrase and neuraminidase inhibitors from Alpinia zerumbet. J Agric Food Chem 59(7):2857-2862

Urhausen A, Torsten A, Wilfried K (2003) Reversibility of the effects on blood cells, lipids, liver function and hormones in former anabolic-androgenic steroid abusers. J Steroid Biochem Mol Biol 84(2):369-375

Vankar PS, Tiwari V, Singh LW, Swapana N (2006) Antioxidant properties of some exclusive species of zingiberaceae family of Manipur. J Environ Agric Food Chem 5:1318-1322

Vanwyk BE, Wink M (2009) Medicinal plant of the world, 1st edn. Briz Publication, South Africa

Wang YC, Huang TT (2005) Screening of anti-Helicobacter pylori herbs deriving from Taiwanese folk medicinal plants. FEMS Immunol Med Microbiol 43(2):295-300

Weerakkody NS, Caffin N, Lambert LK, Turner MS, Dykes GA (2011) Synergistic antimicrobial activity of galangal (Alpinia galanga), rosemary (Rosmarinus officinalis) and lemon iron bark (Eucalyptus staigerana) extracts. J Sci Food Agric 91(3):461-468

Williams RJ, Spencer JPE, Rice-Evans C (2004) Flavonoids: antioxidants or signalling molecules? Free Radic Biol Med 36(7):838-849
Wu TL, Larson K (2000) Zingiberaceae. In: Wu Raven (ed) Flora of China, vol 24. Missouri Botanical Garden Publishing, St. Louis, pp 360-363

Xu JJ, Tan NH, Xiong J, Adebayo AH, Han HJ, Zeng GZ, Ji CJ, Zhang YM, Zhu MJ (2009) Oxyphyllones A and B, novel sesquiterpenes with an unusual 4,5-secoeudesmane skeleton from Alpinia oxyphylla. Chin Chem Lett 20:945-948

Yadav PN, Liu Z, Rafi MMR (2003) A diarylheptanoid from lesser galangal (Alpinia officinarum) inhibits proinflammatory mediators via inhibition of mitogen-activated protein kinase, p44/42, and transcription factor nuclear factor-kappa B. J Pharmacol Exp Ther 305(3):925-931

Yang HL, Chen SC, Chen CS, Wang SY, Hseu YC (2008) Alpinia pricei rhizome extracts induce apoptosis of human carcinoma $\mathrm{KB}$ cells via a mitochondria-dependent apoptotic pathway. Food Chem Toxicol 46:3318-3324

Yasuharaa T, Mansea Y, Morimotoa T, Qilongb W, Matsudab H, Yoshikawab M, Muraoka O (2009) Acetoxybenzhydrols as highly active and stable analogues of $1^{\prime} \mathrm{S}-1^{\prime}$-acetoxychavicol, a potent antiallergic principal from Alpinia galanga. Bioorg Med Chem Lett 19:2944-2946

Yu X, An L, Wang Y, Zhao H, Gao C (2003) Neuroprotective effect of Alpinia oxyphylla Miq. fruits against glutamate-induced apoptosis in cortical neurons. Toxicol Lett 144(2):205-212

Yu YS, Hsu CL, Yen GC (2009) Anti-inflammatory effects of the roots of Alpinia pricei Hayata and its phenolic compounds. J Agric Food Chem 57(17):7673-7680

Yusoff MM, Ibrahim H, Hamid NA (2011) Chemical characterization and antimicrobial activity of rhizome essential oils of very closely allied Zingiberaceae species endemic to Borneo: Alpinia ligulata K. Schum. and Alpinia nieuwenhuizii Val. Chem Biodivers 8(5):916-923

Zhang X, Shi GF, Liu XZ, An LJ, Guan S (2011a) Anti-ageing effects of protocatechuic acid from Alpinia on spleen and liver antioxidative system of senescent mice. Cell Biochem Funct 29(4):342-347

Zhang ZJ, Cheang LC, Wang MW, Li GH, Chu IK, Lin ZX, Lee SM (2011b) Ethanolic extract of fructus Alpinia oxyphylla protects against 6-hydroxydopamine-induced damage of PC12 cells in vitro and dopaminergic neurons in zebrafish. Cell Mol Neurobiol 32(1):27-40 